\title{
Impact of the Atlantic Warm Pool on precipitation and temperature in Florida during North Atlantic cold spells
}

\author{
Timme H. Donders • Hugo Jan de Boer • \\ Walter Finsinger • Eric C. Grimm - Stefan C. Dekker • \\ Gert Jan Reichart • Friederike Wagner-Cremer
}

Received: 28 April 2009/Accepted: 29 October 2009/Published online: 18 November 2009

(C) The Author(s) 2009. This article is published with open access at Springerlink.com

\begin{abstract}
Recurrent phases of increased pine at Lake Tulane, Florida have previously been related to strong stadials terminated by so-called Heinrich events. The climatic significance of these pine phases has been interpreted in different ways. Using a pollen-climate inference model, we quantified the climate changes and consistently found that mean summer precipitation $\left(P_{\mathrm{JJA}}\right)$ increased $(0.5-0.9 \mathrm{~mm} /$ day $)$ and mean November temperature increased $\left(2.0-3.0^{\circ} \mathrm{C}\right)$ during pine phases coeval with Heinrich events and the Younger Dryas. Marine sea surface
\end{abstract}

Donders and De Boer are joint lead authors.

Electronic supplementary material The online version of this article (doi:10.1007/s00382-009-0702-9) contains supplementary material, which is available to authorized users.

T. H. Donders · W. Finsinger · F. Wagner-Cremer Laboratory of Palaeobotany and Palynology,

Institute of Environmental Biology, Utrecht University,

Budapestlaan 4, 3584 CD Utrecht, The Netherlands

T. H. Donders

TNO Geological Survey of the Netherlands,

P.O. Box 80015, 3508 TA Utrecht, The Netherlands

H. J. de Boer $(\square) \cdot$ S. C. Dekker

Department of Environmental Sciences,

Faculty of Geosciences, Utrecht University,

P.O. Box 80115, 3508 TC Utrecht, The Netherlands

e-mail: h.deboer@geo.uu.nl

E. C. Grimm

Illinois State Museum, Research and Collections Center,

1011 East Ash Street, Springfield, IL 62703, USA

G. J. Reichart

Geochemistry, Department of Earth Sciences,

Faculty of Geosciences, Utrecht University,

P.O. Box 80021, 3508 TA Utrecht, The Netherlands temperature records indicate that potential sources for these moisture and heat anomalies are in the Gulf of Mexico and the western tropical Atlantic. We explain this low latitude warming by an increased Loop Current facilitated by persistence of the Atlantic Warm Pool during summer. This hypothesis is supported by a climate model sensitivity analysis. A positive heat anomaly in the Gulf of Mexico and equatorial Atlantic best approximates the polleninferred climate reconstructions from Lake Tulane during the (stadials around) Heinrich events and the Younger Dryas.

Keywords Heinrich events - Abrupt climate change · Atlantic Warm Pool · Loop Current · Low latitudes . Florida

\section{Introduction}

Paleoecological reconstructions spanning the past $60 \mathrm{ka}$ (all ages cal BP) from Lake Tulane (subtropical central Florida, USA, Fig. 1) revealed a series of sharp vegetation switches from open scrub-oak and prairie communities to pine dominated forests (Grimm et al. 1993, 2006). A recently improved age model (Grimm et al. 2006) shows that the pine phases (TP1-TP6) coincide with strong North Atlantic stadials that are terminated by massive iceberg discharges known as Heinrich events (H-events H1-H6) (Heinrich 1988; Bond et al. 1992, 1993). Pine phases at Lake Tulane were initially interpreted as indicative of wetter and cooler periods (Grimm et al. 1993), whereas the most recent interpretation considers them to represent wetter and warmer conditions in Florida (Grimm et al. 2006). The latter interpretation would involve a strong antiphase relationship between climate in Florida and the 
Fig. 1 Location of Lake Tulane (red circle), surface sediment samples used in the calibration (empty circles), and marine sites (blue circles) discussed in the text. Arrows indicate approximate large-scale warm sea-surface circulation (Cherubin et al. 2005). Red contours indicate September SSTs. SSTs $>28.5^{\circ} \mathrm{C}$ indicate the Atlantic Warm Pool

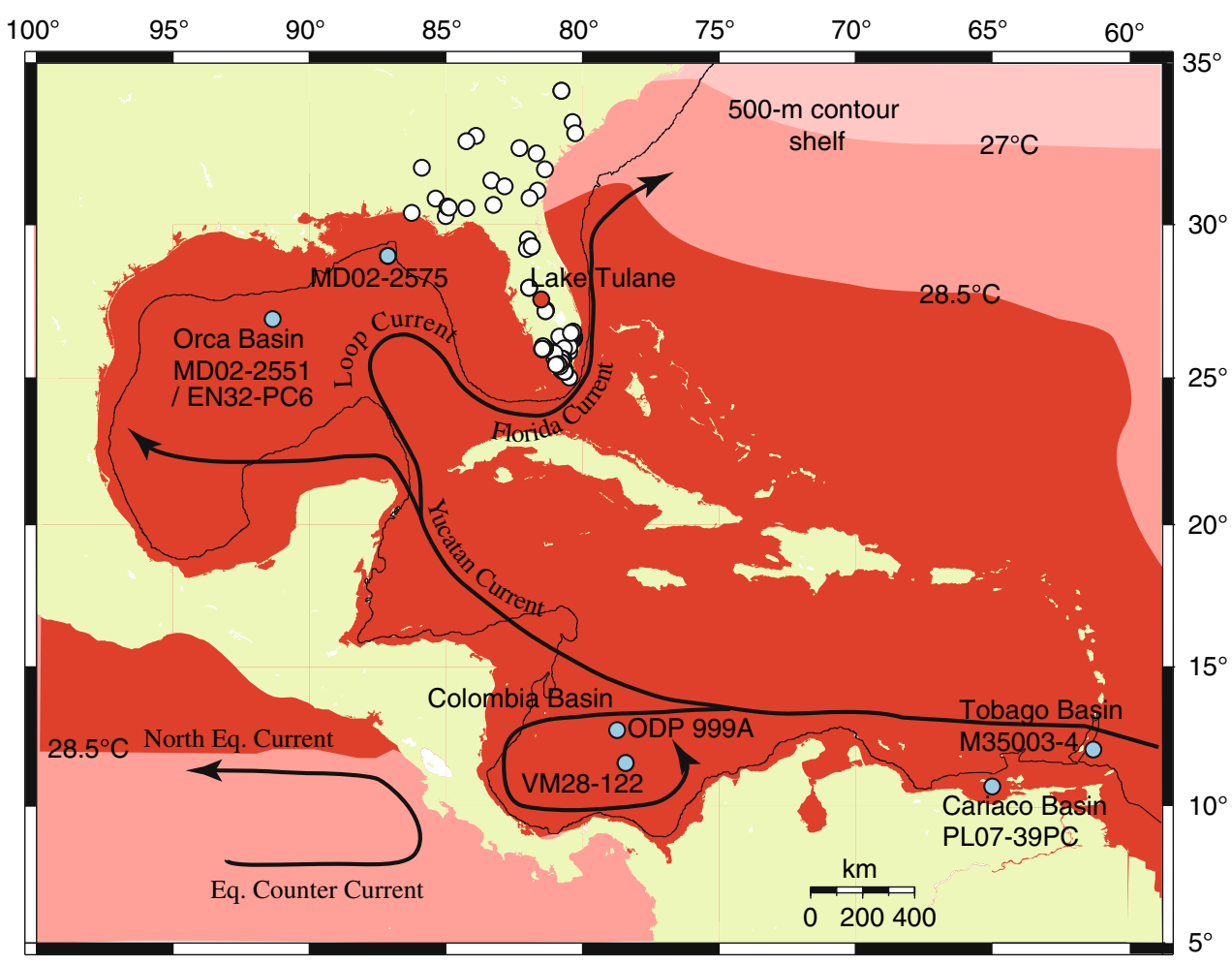

North Atlantic region, and strengthens the concept of low latitude warming in response to North Atlantic surface freshening and subsequent reduction of the Atlantic Meridional overturning circulation (AMOC) (e.g. Stocker 1998; Rühlemann et al. 1999; Flower et al. 2004).

More evidence for the linkage between North Atlantic Cooling events and the AMOC comes from climate model simulations (e.g. Rahmstorf 1996; Ganopolski and Rahmstorf 2001; Flückiger et al. 2008). Proxy records of water mass reorganisation (e.g. Charles et al. 1996; Vidal et al. 1997; Rühlemann et al. 1999; McManus et al. 2004) also indicate abrupt reductions in northward heat transport during these time intervals. However, with regard to changes in low latitude Atlantic Sea surface temperatures (SSTs), model and proxy studies show less agreement. Although some combined climate model and proxy studies suggest a warming of low latitude Atlantic SSTs (e.g. Rühlemann et al. 2004; Menviel et al. 2008, Flückiger et al. 2008), the results of several other SST reconstructions are not uniform in sign and magnitude (Lea et al. 2003; Flower et al. 2004; Hill et al. 2006; Ziegler et al. 2008) (Fig. 3).

The size and northward expansion of the Atlantic Warm Pool (AWP) could hold the key to explaining the observed antiphase relationship between North Atlantic cooling and warming over Florida. The AWP is a region of surface waters warmer then $28.5^{\circ} \mathrm{C}$ and comprises the Gulf of Mexico (GoM), Caribbean Sea and the western tropical North Atlantic (Wang and Enfield 2001; Wang et al. 2006) during summer in the present day climate (Fig. 1). In the present-day climate, the AWP reaches its northern most position in September. The size and northward extent of the AWP in summer determines the summer position of the Inter-tropical Convergence Zone (ITCZ) and thereby affects precipitation and trade winds over the (sub)tropical North Atlantic region. Summer trade winds over the (sub)tropical North Atlantic partly drive the flow of warm surface waters from the Caribbean Sea through the GoM by the Loop Current (Johns et al. 2002).

To investigate the relation between low latitude SSTs and Florida climate, we provide an objective quantitative climate reconstruction from Lake Tulane based on newly developed pollen-climate inference models. We compare these results with available SST records from the (sub)tropical Atlantic section of the AMOC that are potential source areas for enhanced precipitation in Florida (Chen and Gerber 1992). The now fully layer-counted NGRIP Greenland ice core (Rasmussen et al. 2008; Svensson et al., 2008) provides an improved chronological framework, which allows better assessment of the correlation with South Florida. We use contrasting low-latitude Atlantic SST reconstructions as a basis for a series of climate model sensitivity experiments. Based on our model results, we discuss the mechanistic relation between lowlatitude SST anomalies, specifically the role of Loop Current intensity, and land-surface temperature and precipitation changes in Florida during the periods with presumed AMOC reorganizations. 


\section{Environmental setting and data}

Lake Tulane is one of numerous deep sinkhole lakes on the Lake Wales Ridge highland in south-central Florida (Fig. 1), which locally rises to $55 \mathrm{~m}$ elevation. Unconsolidated sands cause the area to be excessively well drained with highly permeable soils. As a consequence, natural vegetation on the Lake Wales Ridge consists mainly of a mosaic of sand pine scrub and sandhill high pine communities. The first consists of scrub oak species (Quercus myrtifolia, $Q$. inopina, $Q$. geminata, $Q$. chapmanii), rosemary (Ceratiola ericoides), rusty lyonia (Lyonia ferruginea), and palmettos (Serenoa repens and Sabal etonia), with scattered sand pine (Pinus clausa) while the second is dominated by South Florida slash pine (Pinus elliottii var. densa), with wire grass (Aristida stricta) and scrub (Quercus laevis, Carya floridana) undergrowth (Abrahamson et al. 1984; Grimm et al. 2006). The vegetation mosaic depends largely on precipitation during the wet summer-growing season. The sandy soils and seasonal precipitation make the site sensitive to regional climate variations.

Our principal dataset consists of pollen counts on 191 samples taken from an 18-m long core collected at Lake Tulane (Grimm et al. 2006). To assess within and between site variability, we use pollen records from an earlier core collected at Lake Tulane (Grimm et al. 1993) and a record from Lake Annie $100 \mathrm{~km}$ south of Lake Tulane (Watts 1975; Supplemental material 138 S1, Fig. S3). A study by Willard et al. (2007) from Tampa Bay that shows significant dry/wet variations was assessed but was not used in the quantitative climate reconstruction because the catchment area and depositional setting of that site vary strongly through time, whereby changes in local vegetation disproportionately drive the results. All pollen percentages were calculated based on the taxonomical resolution of pollen counts from modern surface sediments (Whitmore et al. 2005).

\section{Methods}

\subsection{Transfer-function development and climate reconstruction}

In addition to the previous qualitative interpretations (Grimm et al. 1993, 2006) we use numerical methods to quantitatively reconstruct past climate changes based on the Lake Tulane pollen records. Regional pollen-based climate inference models were developed using an extensive compilation of (bio)climatic data (Whitmore et al. 2005) and pollen counts from surface sediment samples (Whitmore et al. 2005; Donders et al. 2005a). Our selection covers wide temperature and precipitation gradients (tropical to warm-temperate) across the SE USA (Fig. 1; Supplemental material S1). In attempt to increase the predictive power of the inference models (Table 1), we limited wide-ranging genera (e.g. Carya, Quercus, Pinus) to species with shorter environmental variables by excluding surface sediment samples from more temperate areas. The individual explanatory power of 36 (bio)climatic parameters was assessed using canonical correspondence analysis (CCA)(Supplemental material S1). The ecologically and statistically most significant parameters, mean summer precipitation $\left(P_{\mathrm{JJA}}\right)$ and mean November temperature $\left(T_{\mathrm{NOV}}\right)$, were tested and selected as predictands for the pollen-climate inference models (Table 1; Supplemental material S1). Inference models were derived by partial least squares (PLS) and weighted-averaging PLS (WA-PLS) with bootstrap cross-validated prediction errors. These methods have been used successfully for pollenclimate inferences (e.g. Finsinger et al. 2007) and are considered robust methods (Birks 2004), especially for predictions within the calibration range. To assess the reliability of the reconstruction and detect possible problematic intervals, a goodness-of-fit statistic was calculated for $P_{\mathrm{JJA}}$ and $T_{\mathrm{NOV}}$. For each variable the squared residual distance was calculated using a CCA with a single environmental variable, providing an estimate of the fit of the environmental variable with the calibration data.

\subsection{Climate model sensitivity experiments}

We performed climate model sensitivity experiments with the Earth-system model of intermediate complexity (EMIC) PUMA-2 (Fraedrich et al. 1998, 2005a, b) to investigate the sensitivity of the land-surface climate in Florida to SST anomalies in the (extra) tropical North Atlantic, Caribbean Sea, and GoM. PUMA-2 is a general circulation model (GCM) with relatively low

Table 1 Pollen-climate inference model performance for winter and summer precipitation $\left(P_{\text {win }}, P_{\text {sum }}\right)$, and November temperature $\left(T_{\text {nov }}\right)$

\begin{tabular}{llll}
\hline & $\begin{array}{l}P_{\mathrm{djf} \text { (winter) }} \\
(\mathrm{mm} / \text { season) }\end{array}$ & $\begin{array}{l}P_{\mathrm{JJA} \text { (summer }} \\
(\mathrm{mm} / \text { season) }\end{array}$ & $T_{\mathrm{NOV}}\left({ }^{\circ} \mathrm{C}\right)$ \\
\hline \% Variance & 10.8 & 9.8 & 11.8 \\
Model type & WA-PLS & PLS & WA-PLS \\
Gradient length & 1.576 & 1.846 & 1.557 \\
\# Components & 2 & 2 & 2 \\
RMSEP & 31.32 & 39.7 & 1.9 \\
$R^{2}$ boot & 0.76 & 0.66 & 0.62 \\
\# Outliers removed & 3 & 2 & 2 \\
RMSEP \% range & 11.9 & 17.9 & 15.3 \\
\hline
\end{tabular}


computational demand, yet simulates an atmospheric response to SST forcing comparable to the more complex ECHAM4 (Romanova et al. 2006; Grosfeld et al. 2007, 2008). To represent details of the Florida region, the model is used in a T42 spectral triangular resolution with 10 vertical layers. We performed four climate model simulations: a last glacial maximum (LGM, $21 \mathrm{ka}$ ) reference (EMIC-LGM) with prescribed LGM boundary conditions for SSTs, solar insolation and atmospheric $\mathrm{CO}_{2}$ concentrations $(200 \mathrm{ppmv})$ and three climate sensitivity simulations with idealized SST anomalies (Table 2). In the sensitivity simulations, we altered only the prescribed SSTs to constrain potential source areas for the land-surface temperature and precipitation anomalies seen in Florida during $\mathrm{H}$-events. Each simulation is run for 40years and started from an atmosphere at rest. Because SSTs are prescribed, the model's spin-up time requires at most 20 years. To reduce model noise, climatology is calculated as an average of the last 20 years of each simulation.

Monthly LGM SSTs and sea-ice boundary conditions are based on the GLAMAP dataset (Schäfer-Neth and Paul 2003), glacial ice cover, orography, sea level, and coastlines follow Peltier (1994), and LGM vegetation is based on Crowley (1995) and Martin (1998) (Fig. S4). In the EMIC-H0 simulation (Fig. 2a), SST boundary conditions were based on the assumption that, relative to LGM conditions, a decrease in northwards heat transport resulted in a zonal average SST cooling (of maximum $6^{\circ} \mathrm{C}$ ) in the extra-tropical North Atlantic during the last H-event (after Bond et al. 1992, 1993). The EMIC-H1 simulation (Fig. 2b) represents, besides North Atlantic cooling, increased low latitude summer insolation resulting in a maximum $2^{\circ} \mathrm{C}$ zonal average warming of the equatorial surface waters (after Schmidt et al. 2004; Ziegler et al. 2008). The EMIC-H + simulation (Fig. 2c) additionally includes increased zonal heat transport from the tropical East Atlantic, through the Caribbean Sea into the GoM, representing an intensification of the Loop Current. SSTs in EMIC-H + simulation increase $1-2^{\circ} \mathrm{C}$ close to Florida (after Flower et al. 2004), relative to the LGM simulation (see Supplemental material S2 for details on simulations).

\section{Results}

\subsection{Pollen-inferred climate reconstruction}

Inference model data show that during the TP1-TP6 phases, coeval with strong Greenland stadials, mean summer precipitation $\left(P_{\mathrm{JJA}}\right)$ increased by $0.5-0.9 \mathrm{~mm} /$ day, while November temperature $\left(T_{\mathrm{NOV}}\right)$ increased by $2.0-3.0^{\circ} \mathrm{C}$ (Fig. 3). Reconstruction results from two independent datasets from Lake Tulane are highly consistent and offsets between records do not exceed the bootstrapped prediction errors (Table 1; Supplemental material S1, Fig. S3). The Lake Tulane signals for $0-13 \mathrm{ka}$ agree with the reconstruction from nearby Lake Annie (Supplemental material S1, Fig. S3).

Remarkable features at both sites are the consistently dry/cool conditions in the Allerød and warm/wet conditions during (part of) the Younger Dryas (YD). Increased wetness during the Middle Holocene is consistent with independent reconstructions from South Florida (Donders et al. 2005b). A coastal pollen record from Tampa Bay (Willard et al. 2007) partly confirms this result, showing wet conditions during $\mathrm{H} 1$ and a stepwise change during the YD that mirrors the changes seen in the Tulane 06 record, but not the Tulane 93 and Lake Annie records. The length of the wet phase in the YD is therefore unclear. The middle Holocene temperature increase is remarkably high compared to the glacial-interglacial transition. Early Holocene vegetation stands out as an intermediate phase in the record (Grimm et al. 2006), with abundant Quercus and some Ambrosia, but low heath and intermediate Pinus abundance. In the calibration dataset, Ambrosia is generally more abundant in temperate areas due to forest clearance and land disturbance, which possibly skews the reconstruction to somewhat lower winter temperatures during the LGM and early Holocene. Figure S3 shows the goodness-of-fit with $90 \%$ percentile cutoff values. Only the lowest $T_{\mathrm{NOV}}$ reconstruction values between 21 and $20 \mathrm{ka}$ BP are uncertain since the transfer model does not perform well in that interval. Our reconstruction data are reliable during the TP1-TP6 phases. Warming during these phases is also indicated qualitatively by lower Ambrosia abundances, because warm winters inhibit Ambrosia to germinate effectively (Bazzaz 1974).

Table 2 Description of the climate model simulations, SST boundary conditions and reference to the SST reconstruction on which the simulation is based

\begin{tabular}{lll}
\hline Simulation & SST boundary conditions & Reference \\
\hline EMIC-LGM & GLAMAP monthly & Schäfer-Neth and Paul (2003) \\
EMIC-H0 & As EMIC-LGM with North-Atlantic cooling & Bond et al. (1992, 1993) \\
EMIC-H1 & As EMIC-H0 with increased low latitude summer insolation & Bond et al. (1992, 1993, 2004), Ziegler et al. (2008) \\
EMIC-H+ & As EMIC-H1 with Loop Current intensification & Flower et al. (2004) \\
\hline
\end{tabular}



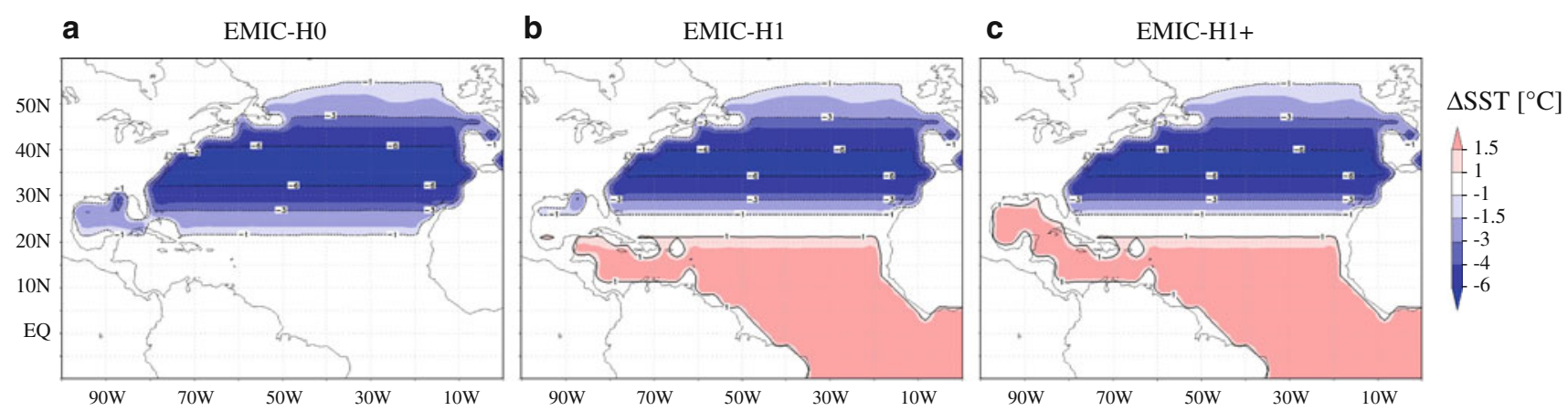

Fig. 2 Boundary conditions for the EMIC-H0, EMIC-H1 and EMIC-H+ climate sensitivity simulations, relative to those used in the EMICLGM control simulation

Age uncertainties of the Lake Tulane record (Grimm et al. 2006) are larger than the NGRIP ice core record (Svensson et al. 2008), but in TP-0-2 do not exceed $1.5 \mathrm{ka}$, and only for TP-5 and 6 exceed the duration of the event. Especially for the pine phases TP1-3 we can confidently state that they correlate to Greenland Stadials (Fig. 3) that include a Heinrich event, since the latter have been correlated independently to the Greenland ice cores (Stoner et al. 2000). The warm/wet TP2 and TP4 phases start well before and extend beyond $\mathrm{H} 2$ and $\mathrm{H} 4$, respectively. Despite uncertainties in both the Heinrich ages and the Lake Tulane chronology (see Stoner et al. 2000; Grimm et al. 2006), this long duration seems robust. Confining the duration of TP2 and TP4 events exactly to $\mathrm{H} 2$ and $\mathrm{H} 4$ would require an unrealistic threefold increase in sedimentation rate during the pine phases. See also Grimm et al. (2006) for a more extended discussion on the age uncertainties of the Lake Tulane record.

\subsection{Climate sensitivity to Atlantic SSTs}

Our climate sensitivity experiments indicate that the climate in Florida is sensitive to changes in both low- and highlatitudinal (North) Atlantic SSTs. Figure 4 shows modeled land-surface temperature and precipitation (anomalies) for Florida (averaged over $75-88^{\circ} \mathrm{W}$ to $25-30^{\circ} \mathrm{N}$ ). Summer precipitation varies strongly between experiments; while winter is consistently modeled as dry and summer as wet (Fig. 4a, b), the EMIC-H+ simulation shows the strongest seasonality. All simulations produce a drier climate compared to the pollen-inferred reconstructions $\left[P_{\mathrm{JJA}}\right.$ of $5-$ $6 \mathrm{~mm} /$ day based on pollen, and 1.4 (EMIC-LGM), 0.8 (EMIC-H0), 1.2 (EMIC-H1) and $1.7 \mathrm{~mm} /$ day (EMIC-H+) simulated] and peak precipitation is delayed by 1 month. Only the EMIC-H+ simulation explains the magnitude of the pollen-inferred $P_{\mathrm{JJA}}$ increase from LGM to H1. This increase in summer precipitation is related to a localized northward shift of the ITCZ during summer (see Supplemental S3 material, Fig. S6).
Land-surface temperatures vary little between the experiments (Fig. 4c, d). Compared to the EMIC-LGM simulation, all EMIC-H experiments show positive temperature anomalies at the onset of winter and are generally colder during spring, summer, and fall. The largest positive temperature anomaly $\left(1^{\circ} \mathrm{C}\right)$ is simulated in the EMIC-H+ simulation for December. All simulations produce a warmer climate compared to the pollen-inferred reconstructions [ $T_{\mathrm{NOV}}$ of $16-17^{\circ} \mathrm{C}$ based on pollen, and 18 (EMIC-LGM), 18 (EMIC-H0), 19 (EMIC-H1) and $19^{\circ} \mathrm{C}$ (EMIC-H+) simulated]. Relative to the EMIC-LGM simulation, the EMIC-H1 and $\mathrm{EMIC}-\mathrm{H}+$ simulations show a positive temperature anomaly in November $\left(1^{\circ} \mathrm{C}\right)$, while the EMIC-H0 simulation shows little change. The results indicate that a warming of the equatorial Atlantic and the GoM is needed to explain the pollen-inferred increase in summer precipitation and November temperature during North-Atlantic cold spells.

\section{Discussion}

\subsection{Source of heat and moisture anomalies}

To explain the observed increases in precipitation and temperature in Florida, we hypothesize that the GoM warmed during North Atlantic colds spells and that this warming is potentially related to increased Loop Current (Hofmann and Worley 1986; Poore et al. 2004). Grimm et al. (2006) observed a general inverse correlation to Greenland stadials and the Lake Tulane pollen record, both on independent chronologies. With the quantitative temperature data from Lake Tulane and update to the fully layer-counted NGRIP chronology used in Fig. 3, this conclusion is strengthened here. However, different SST records do not show a clear and unequivocal regional lowlatitude warming (Fig. 3).

At present, the Loop Current is controlled by an interplay between regional surface winds and water flow from 


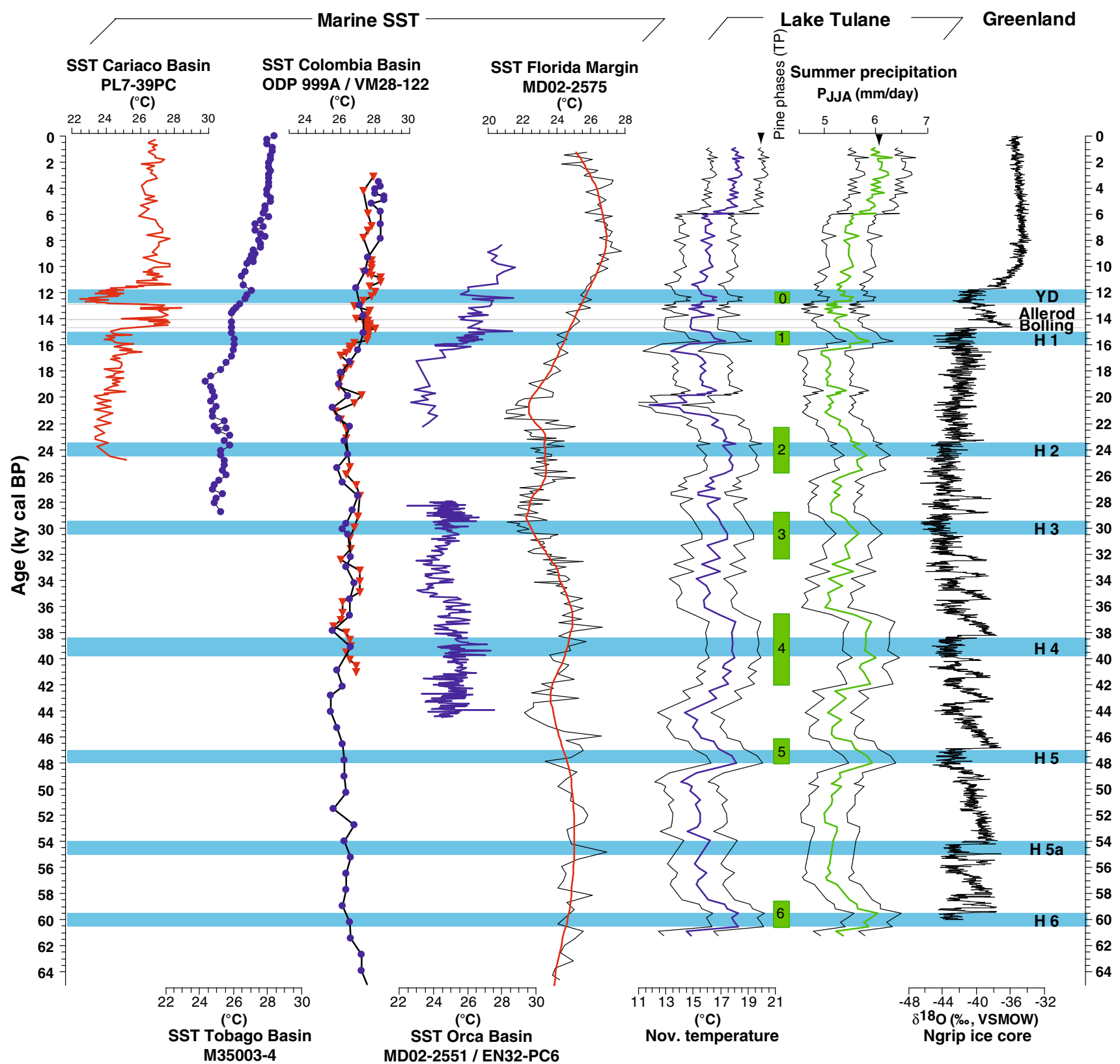

Fig. 3 Paleoclimate reconstructions from Lake Tulane based on the pollen climate inference models for the last $60 \mathrm{kyr}$. The Lake Tulane chronology is based on 55 AMS ${ }^{14} \mathrm{C}$ ages that were calibrated with the intcal04 (Reimer et al. 2004) for ages younger than $20,000{ }^{14} \mathrm{C}$ yr BP, and with the Fairbanks et al. (2005) calibration curve (based on paired AMS ${ }^{14} \mathrm{C} / \mathrm{U}$-series dating of corals) for ages $20,000-40,000{ }^{14} \mathrm{C} \mathrm{yr}$ BP. Phases TP5 and TP6 are not independently dated but correlated to $\mathrm{H} 5$ and H6, analogous to the observed correlation of TP1-TP4 with H1-H4 (see Grimm et al. 2006 for more details). Arrows indicate present day climatic values at Lake Tulane. Data is compared to the regional marine SST records from the Cariaco Basin (Lea et al. 2003), Tobago Basin (Rühlemann et al. 1999), Colombia Basin (Schmidt et al. 2004), Orca Basin (Hill et al. 2006; Flower et al. 2004) and

the Caribbean Sea through the Yucatan Channel (Johns et al. 2002; Romanou et al. 2004; Cherubin et al. 2005). These studies indicate that a northerly ITCZ position
Florida Margin (Ziegler et al. 2008). Blue bars indicate maximum calendar age ranges of North Atlantic iceberg-rafted debris (IRD) deposition, following Stoner et al. (2000). Depending on the record used, the exact timing and duration of Heinrich events vary (Rashid et al. 2003). We consider the estimates based on correlation between paleomagnetic intensity measured in sediment records close to Greenland and cosmogenic isotopes fluxes measured in the GISP2 Greenland ice core record (Stoner et al. 2000) as most reliable, and use these for data comparison. Heinrich event ages, and hence the Lake Tulane record below TP4, have been updated to the new Greenland Ice Core Chronology 2005 (GICC05), which is based on layer counting of the NGRIP ice core back to $60 \mathrm{ka}$ (Rasmussen et al. 2008; Svensson et al. 2008)

during summer enhances the intrusion of the Loop Current because the associated (south)easterly trade winds enhance the northwestward advection of warm surface waters. 

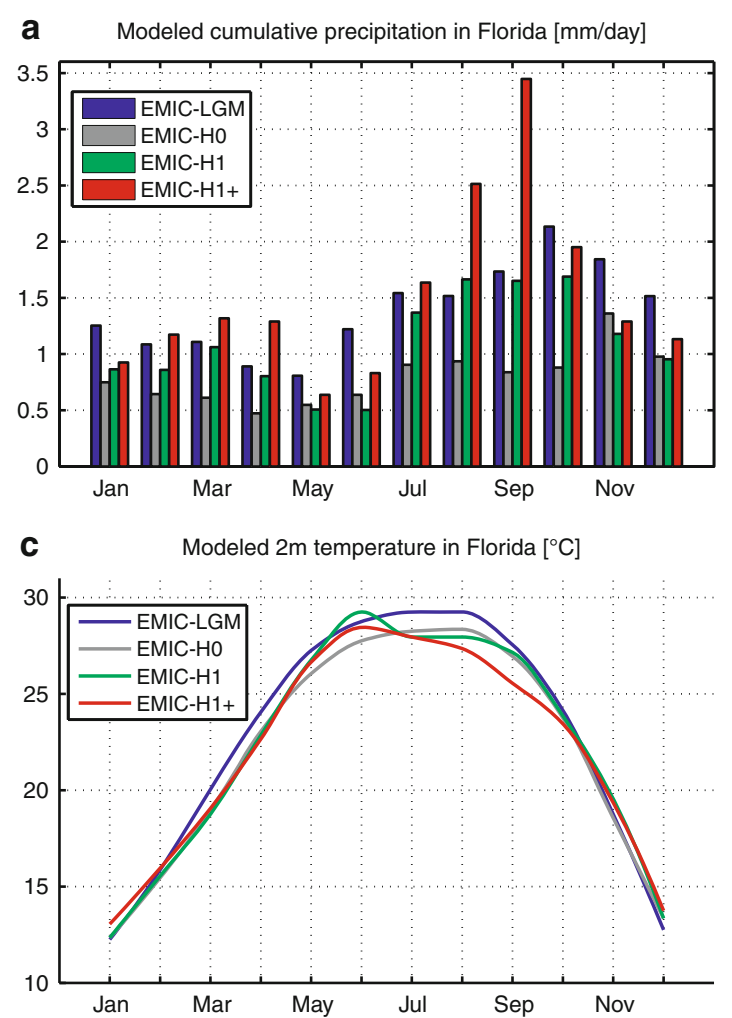

Fig. 4 Simulated land surface temperature and precipitation for the Florida region. Simulated monthly precipitation (a) and precipitation anomalies relative to LGM simulation (b) are averaged over the larger Florida region $\left(75-88^{\circ} \mathrm{W}\right.$ to $\left.25-30^{\circ} \mathrm{N}\right)$ including grid-cells over water.

Hodell et al. (1991) and Poore et al. (2004) indicate that during the Holocene the Loop Current was mainly controlled by the effect of summer insolation on ITCZ position. Nürnberg et al. (2008) reconstructed SSTs and sea surface salinities in the northeastern GoM (Florida margin) over the past $400 \mathrm{kyr}$. Their results reveal that Loop Current intrusion was modulated by the northward extend of the AWP and freshwater discharge from the Laurentide Ice Sheet. All these studies indicate a positive relation between a northerly ITCZ position and Loop Current intrusion. Observational evidence suggests that the ITCZ moved south during periods of North Atlantic cooling (Wang et al. 2005; Stott et al. 2002; Burns et al. 2003; Muller et al. 2008). These observations are supported by simulations with various climate models (Zhang and Delworth 2005; Stouffer et al. 2005). If the ITCZ was indeed displaced south over the western Atlantic region, this would cause a decrease in summer trade winds and a reduction of the associated advection of warm surface waters through the GoM. However, based on the coincidence between our climate model simulations and pollen-based climate reconstructions, we infer that heat transport up to and through the GoM potentially increased, suggesting an

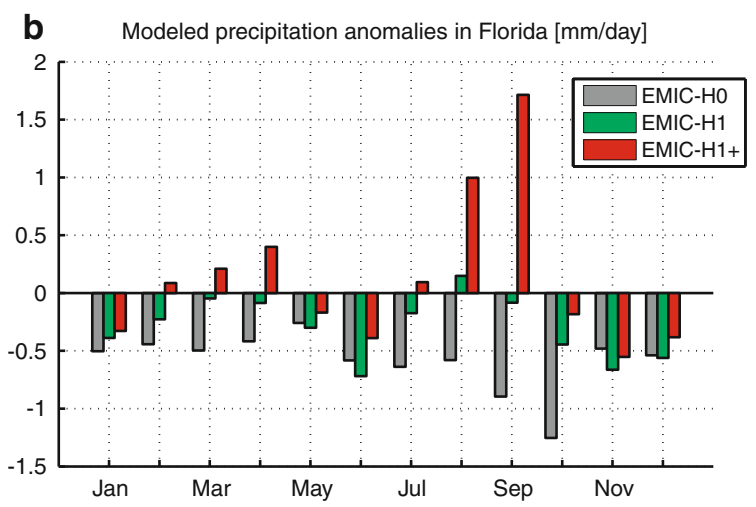

d Modeled $2 \mathrm{~m}$ surface temperature anomalies in Florida $\left[{ }^{\circ} \mathrm{C}\right]$

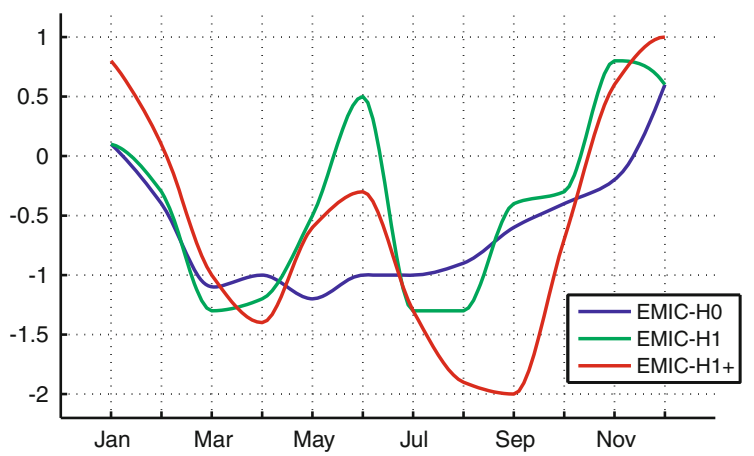

Simulated monthly land surface $(2 \mathrm{~m})$ temperature (c) and temperature anomalies relative to LGM simulation (d) are averaged over terrestrial grid-cells in the Florida region $\left(75-88^{\circ} \mathrm{W}\right.$ to $\left.25-30^{\circ} \mathrm{N}\right)$

increase in summer trade winds and a northerly position of the ITCZ over the region.

We explain this apparent contradiction by an increase in heat transport up to and through the GoM forced by increased summer trade winds driven by a steepened equator-pole temperature gradient during North Atlantic cold spells. Ziegler et al. (2008) indicate that summer expansion of the AWP is generally insensitive to extratropical North Atlantic cooling. A persistent AWP, combined with a warm GoM should therefore allow for a northerly ITCZ position over the eastern tropical North Atlantic during boreal summer and could provide moisture and heat to Florida. The highest SST increase during H1 is seen in the central GoM (Flower et al. 2004) (Fig. 1, 3), which is directly influenced by the warm waters of the Loop Current (DeHaan and Sturges 2005). Koutavas et al. (2002) found evidence for decreased trade-winds with a lower equator-pole temperature gradient during LGM based on reduced upwelling offshore Peru. Conversely, increased equator-pole temperature gradient enhanced Hadley circulation during North Atlantic cold spells (Jain et al. 1999; Trenberth et al. 2000; Clement et al. 2004). The increase in Hadley 
circulation possibly led to an increase in easterly trade winds over the western equatorial North Atlantic in summer (Zhang and Delworth 2005), thereby enhancing Loop Current intrusion into the GoM and warming the surface waters around the Florida peninsula.

The observed increase of summer precipitation and November temperature in Florida could therefore represent an increase in summer trade winds and reflect the persistence of the AWP and increased Loop Current during North Atlantic cold spells (Nürnberg et al. 2008; Ziegler et al. 2008). It contrasts the presumed same-sign synchronicity of low and high latitude climates during the late Glacial as observed in a planktic foraminiferal $\mathrm{Mg} / \mathrm{Ca}$ record from the Cariaco Basin on the northern Venezuelan shelf (Lea et al. 2003). Analogous to well-known precipitation decrease at Cariaco during stadials (e.g. Haug et al. 2001; González et al. 2008), the SST cooling has been explained by invoking a mean southward migration of the ITCZ (Lea et al. 2003), which should reduce summer precipitation in Florida (e.g. Chen and Gerber 1992; Enfield et al. 2001). However, the Cariaco SST decrease during the YD is large $\left(3-4^{\circ} \mathrm{C}\right)$ relative to other records from the AWP (Fig. 3), and probably shows a winter upwelling signal in a restricted marine basin (Ziegler et al. 2008). Moreover, marine records from the western tropical Atlantic show SST increases (Tobago Basin), and terrestrial wet conditions with SST and sea surface salinity increases (offshore NE Brazil) during $\mathrm{H} 1$ and the YD (Rühlemann et al. 1999; Jennerjahn et al. 2004; Weldeab et al. 2006). These reconstructions are best explained by a more southward ITCZ position during stadial (boreal) winters. Farther north, reconstructed summer SSTs also show conflicting patterns. In the central GoM a clear warming during $\mathrm{H} 1$ is present (Flower et al. 2004), while summer SSTs from the Florida margin (MD02-2575) do not show consistent warming during YD and $\mathrm{H}$-events (Ziegler et al. 2008). However, the pre-Holocene long term temperature trends between MD02-2575 and Lake Tulane correspond remarkably well (Fig. 3).

Ziegler et al. (2008) explain contrasting regional paleo SST patterns by invoking a strongly seasonally biased climate response to North Atlantic cold events in the tropical Atlantic. Their GoM SST signal is controlled by boreal summer insolation that displaces the northern limit of the AWP, while it is relatively insensitive to the millennial-scale YD and $\mathrm{H}$-events that primarily affect boreal winter conditions. Because our Lake Tulane record represents summer-precipitation changes, the variable duration of TP phases might be determined by summer insolation influencing the northern extent of the AWP. This hypothesis is supported by the results of our climate model sensitivity analysis, which indicates that the climate in Florida is relatively insensitive to extra-tropical North Atlantic cooling if the AWP is present. Rather, the clear warm/wet phases during $\mathrm{H}$-events and YD result from heat flow from the AWP into the GoM by summer trade wind forcing.

\subsection{Sensitivity of simulated land surface temperatures}

Altough variation in the simulated $T_{\mathrm{NOV}}$ anomalies in Florida among the EMIC-H0, $-\mathrm{H} 1$, and $-\mathrm{H}+$ simulations is limited, their offsets with the EMIC-LGM simulation is considerable. This contrast indicates that both extratropical North Atlantic cooling and low latitudinal Atlantic warming contribute to the temperature increase. Winter warming of Florida in the EMIC-H simulations relative to the EMIC-LGM simulation coincides with a decrease in winter precipitation in the region (Supplemental material S3). The simulated $T_{\mathrm{NOV}}$ increase could therefore partly be explained by alterations in the surface energy balance related to a decrease in soil moisture and cloudiness (Wild and Ohmura 1999).

The absolute difference between our pollen-inferred and modeled November temperature could be caused by the constant solar forcing prescribed in our model simulations. Insolation changed considerably between the LGM and the last Heinrich event and has an important effect on tropical climate (Clement et al. 2004). Winter insolation decreased by approximately $30 \mathrm{~W} / \mathrm{m}^{2}$ and summer insolation increased by a similar value (Berger and Loutre 1991). Taking into account the decrease in winter insolation would potentially allow for a better match between the pollen-inferred and modeled November temperatures. This account however, would blur the results of the sensitivity analysis and was therefore omitted.

\section{Conclusions}

Increases in summer precipitation and November temperatures in Florida coincided with episodes of extreme cooling in the North Atlantic during Heinrich events and Younger Dryas, the latter of which may contain both a warm/wet and cold/dry subphase. These reconstructed climate changes are best explained by a warming of the surface waters of the tropical Atlantic and the Gulf of Mexico. Surface waters in the Gulf of Mexico potentially warmed by an intensified Loop Current facilitated by a persistent Atlantic Warm Pool and increased easterly trade winds during summer. The inter-tropical convergence zone was generally displaced south of Florida during the glacial and its summer position was controlled by insolation changes and the extent of the Atlantic Warm Pool. These controls on the inter-tropical convergence zone may have influenced the duration of the lake Tulane pine phases which are associated with wet summer conditions. 
Acknowledgments We thank Jack Williams and Pat Bartlein for providing the modern climate dataset of our Florida surface samples. Oliver Heiri is thanked for his insightful advice on the statistical methods. We greatly appreciate the constructive comments from two reviewers and the editorial comments from Jean Claude Duplessy. Partial funding received from United States National Science Foundation grant ATM-9405145 and from the High Potential Program from Utrecht University.

Open Access This article is distributed under the terms of the Creative Commons Attribution Noncommercial License which permits any noncommercial use, distribution, and reproduction in any medium, provided the original author(s) and source are credited.

\section{References}

Abrahamson WG, Johnson AF, Layne AN, Peroni PA (1984) Vegetation of the Archbold Biological Station, Florida: an example of the southern Lake Wales Ridge. Florida Sci 47:209250

Bazzaz FA (1974) Ecophysiology of Ambrosia artemisiifolia: a successional dominant. Ecology 55:112-119. doi:10.2307/1934623

Berger A, Loutre MF (1991) Insolation Values for the Climate of the Last 10000000 Years. Quat Sci Rev 10:297-317

Birks HJB (2004) Quantitative palaeoenvironmental reconstructions from Holocene biological data. In: Mackay AW, Battarbee RW, Birks HJB, Oldfield F (eds) Global change in the Holocene. Arnold, London, pp 107-123

Bond G, Heinrich H, Broecker W, Labeyrie L, McManus J, Andrews J, Huon S, Jantschik R, Clasen S, Simet C, Tedesco K, Klas M, Bonani G, Ivy S (1992) Evidence for massive discharges of icebergs into the North Atlantic Ocean during the last glacial period. Nature 360:245-249

Bond G, Broecker W, Johnsen S, McManus J, Labeyrie L, Jouzel J, Bonani G (1993) Correlations between climate records from North Atlantic sediments and Greenland ice. Nature 365:143-147

Burns SJ, Fleitmann D, Matter A, Kramers J, Al-Subbary AA (2003) Indian ocean climate and an absolute chronology over Dansgaard/Oeschger events 9 to 13. Science 301:1365-1367

Charles CD, LynchStieglitz J, Ninnemann US, Fairbanks RG (1996) Climate connections between the hemisphere revealed by deep sea sediment core ice core correlations. Earth Planet Sci Lett 142:19-27

Chen E, Gerber JF (1992) Climate. In: Myers RL, Ewel JJ (eds) Ecosystems of Florida. University of Central Florida Press, Orlando, pp 11-34

Cherubin LM, Sturges W, Chassignet EP (2005) Deep flow variability in the vicinity of the Yucatan Straits from a high-resolution numerical simulation. J Geophys Res 110:20

Clement AC, Hall A, Broccoli AJ (2004) The importance of precessional signals in the tropical climate. Clim Dyn 22:327341

Crowley TJ (1995) Ice-Age terrestrial carbon changes revisited. Global Biogeochem Cycles 9:377-389

DeHaan CJ, Sturges W (2005) Deep cyclonic circulation in the Gulf of Mexico. J Phys Oceanogr 35:1801-1812

Donders TH, Wagner F, Visscher H (2005a) Quantification strategies for human-induced and natural hydrological changes in southern Florida wetland vegetation. Quat Res 64:333-342

Donders TH, Wagner F, Dilcher DL, Visscher H (2005b) Mid- to lateHolocene El Niño-Southern Oscillation dynamics reflected in the subtropical terrestrial realm. Proc Natl Acad Sci USA 102:10904-10908
Enfield DB, Mestas-Nuñez AM, Trimble PJ (2001) The Atlantic multidecadal oscillation and its relation to rainfall and river flows in the continental US. Geophys Res Lett 28:2077-2080

Fairbanks RG, Mortlock RA, Chiu T-C, Cao L, Kaplan A, Guilderson TP, Fairbanks TW, Bloom AL, Grootes PM, Nadeau M-J (2005) Radiocarbon calibration curve spanning 0 to 50,000 years BP based on paired $230 \mathrm{Th} / 234 \mathrm{U} / 238 \mathrm{U}$ and $14 \mathrm{C}$ dates on pristine corals. Quat Sci Rev 24:1781-1796

Finsinger W, Heiri O, Valsecchi V, Tinner W, Lotter AF (2007) Modern pollen assemblages as climate indicators in southern Europe. Global Ecol Biogeogr 16:567-582

Flower BP, Hastings DW, Hill HW, Quinn TM (2004) Phasing of deglacial warming and Laurentide Ice Sheet meltwater in the Gulf of Mexico. Geology 32:560-597

Flückiger J, Knutti R, White JWC, Renssen H (2008) Modeled seasonality of glacial abrupt climate events. Clim Dyn 31:633645

Fraedrich K, Kirk E, Lunkeit F (1998) Portable University Model of the atmosphere. Deutsches Klimarechenzentrum, Tech. Rep. $16: 37$

Fraedrich K, Jansen H, Kirk E, Luksch U, Lunkeit F (2005a) The Planet Simulator: towards a user friendly model. Meteorol Z 14:299-304

Fraedrich K, Jansen H, Kirk E, Lunkeit F (2005b) The Planet Simulator: Green planet and desert world. Meteorol Z 14:305314

Ganopolski A, Rahmstorf S (2001) Simulation of rapid glacial climate changes in a coupled climate model. Nature 409:153-158

González C, Dupont LM, Mertens K, Wefer G (2008) Reconstructing marine productivity of the Cariaco Basin during marine isotope stages 3 and 4 using organic-walled dinoflagellate cysts. Paleoceanography 23:PA3215

Grimm EC, Jacobson GL Jr, Watts WA, Hansen BCS, Maasch KA (1993) A 50, 000-year record of climate oscillations from Florida and its temporal correlation with the Heinrich events. Science 261:198-200

Grimm EC, Watts WA, Jacobson GLJ, Hansen BCS, Almquist HR, Dieffenbacher-Krall AC (2006) Evidence for warm wet Heinrich events in Florida. Quat Sci Rev 25:2197-2211

Grosfeld K, Lohmann G, Rimbu N, Fraedrich K, Lunkeit F (2007) Atmospheric multidecadal variations in the North Atlantic realm: proxy data, observations, and atmospheric circulation model studies. Clim Past 3:39-50

Grosfeld K, Lohmann G, Rimbu N (2008) The impact of Atlantic and Pacific Ocean sea surface temperature anomalies on the North Atlantic multidecadal variability. Tellus A 60:728-741

Haug GH, Hughen KA, Sigman DM, Peterson LC, Rohl U (2001) Southward migration of the intertropical convergence zone through the Holocene. Science 293:1304-1308

Heinrich H (1988) Origin and consequences of cyclic ice rafting in the northeast Atlantic Ocean during the past 130, 000 years. Quat Res 29:142-152

Hill HW, Flower BP, Quinn TM, Hollander DJ, Guilderson TP (2006) Laurentide ice sheet meltwater and abrupt climate change during the last glaciation. Paleoceanography 21:PA1006

Hodell DA, Curtis JH, Jones GA, Higueragundy A, Brenner M, Binford MW, Dorsey KT (1991) Reconstruction of Caribbean climate change over the past 10,500 years. Nature 352:790-793

Hofmann EE, Worley SJ (1986) An investigation of the circulation of the Gulf of Mexico. J Geophys Res 91:14221-14236

Jain S, Lall U, Mann ME (1999) Seasonality and interannual variations of northern hemisphere temperature: equator-to-pole gradient and ocean-land contrast. J Clim 12:1086-1100

Jennerjahn TC, Ittekkot V, Arz HW, Behling H, Patzold J, Wefer G (2004) Asynchronous terrestrial and marine signals of climate change during Heinrich events. Science 306:2236-2239 
Johns WE, Townsend TL, Fratantoni DM, Wilson WD (2002) On the Atlantic inflow to the Caribbean Sea. Deep Sea Res I 49:211243

Koutavas A, Lynch-Stieglitz J, Marchitto TM Jr, Sachs JP (2002) El Niño-like pattern in ice age tropical Pacific sea surface temperatures. Science 297:226-230

Lea DW, Pak DK, Peterson LC, Hughen KA (2003) Synchroneity of tropical and high-latitude Atlantic temperatures over the last glacial termination. Science 301:1361-1364

Martin PH (1998) Land-surface characterization in climate models: biome-based parameter inference is not equivalent to local direct estimation. J Hydrol 212:287-303

McManus JF, Francois R, Gherardi JM, Keigwin LD, Brown-Leger S (2004) Collapse and rapid resumption of Atlantic meridional circulation linked to deglacial climate changes. Nature 428:834837

Menviel L, Timmermann A, Mouchet A, Timm O (2008) Meridional reorganizations of marine and terrestrial productivity during Heinrich events. Paleoceanography 23:PA1203

Muller J, Kylander M, Wust R, Weiss D, Martinezcortizas A, Legrande A, Jennerjahn T, Behling H, Anderson W, Jacobson G (2008) Possible evidence for wet Heinrich phases in tropical NE Australia: the Lynchs Crater deposit. Quat Sci Rev 27:468-475

Nürnberg D, Ziegler M, Karas C, Tiedemann R, Schmidt MW (2008) Interacting Loop Current variability and Mississippi River discharge over the past 400 kyr. Earth Planet Sci Lett 272:278-289

Peltier W (1994) Ice age paleotopography. Science 265:195-201

Poore RZ, Quinn TM, Verardo S (2004) Century-scale movement of the Atlantic intertropical convergence zone linked to solar variability. Geophys Res Lett 31:L12214

Rahmstorf S (1996) On the freshwater forcing and transport of the Atlantic thermohaline circulation. Clim Dyn 12:799-811

Rashid H, Hesse R, Piper DJW (2003) Evidence for an additional Heinrich event between $\mathrm{H} 5$ and $\mathrm{H} 6$ in the Labrador Sea. Paleoceanography 18:1077

Rasmussen SO, Seierstad IK, Andersen KK, Bigler M, Dahl-Jensen D, Johnsen SJ (2008) Synchronization of the NGRIP, GRIP, and GISP2 ice cores across MIS 2 and palaeoclimatic implications. Quat Sci Rev 27(1-2):18-28

Reimer PJ, Baillie MGL, Bard E, Bayliss A, Beck JW, Bertrand CJH, Blackwell PG, Buck CE, Burr GS, Cutler KB, Damon PE, Edwards RL, Fairbanks RG, Friedrich M, Guilderson TP, Hogg AG, Hughen KA, Kromer B, McCormac G, Manning S, BronkRamsey C, Reimer RW, Remmele S, Southon JR, Stuiver M, Talamo S, Taylor FW, Van der Plicht J, Weyhenmeyer CE (2004) IntCal04 terrestrial radiocarbon age calibration, 0-26 cal kyr BP. Radiocarbon 46:1029-1058

Romanou A, Chassignet EP, Sturges W (2004) Gulf of Mexico circulation within a high-resolution numerical simulation of the North Atlantic Ocean. J Geophys Res Oceans 109:25

Romanova V, Lohmann G, Grosfeld K (2006) Effect of land albedo, $\mathrm{CO}_{2}$, orography, and oceanic heat transport on extreme climates. Clim Past 2:31-42

Rühlemann C, Mulitza S, Muller PJ, Wefer G, Zahn R (1999) Warming of the tropical Atlantic Ocean and slowdown of thermohaline circulation during the last deglaciation. Nature 402:511-514

Rühlemann C, Mulitza S, Lohmann G, Paul A, Prange M, Wefer G (2004) Intermediate depth warming in the tropical Atlantic related to weakened thermohaline circulation: Combining paleoclimate data and modeling results for the last deglaciation. Paleoceanography 19:1025

Schäfer-Neth C, Paul A (2003) The Atlantic Ocean at the last glacial maximum: objective mapping of the GLAMAP sea-surface conditions. In: Wefer G, Mulitza S, Ratmeyer V (eds) The South Atlantic in the late quaternary: reconstruction of material budgets and current systems. Springer, Berlin, pp 531-548

Schmidt MW, Spero HJ, Lea DW (2004) Links between salinity variation in the Caribbean and North Atlantic thermohaline circulation. Nature 428:160-163

Stocker TF (1998) Climate change: the seesaw effect. Science 282:61-62

Stoner JS, Channell JET, Hillaire-Marcel C, Kissel C (2000) Geomagnetic paleointensity and environmental record from Labrador Sea core MD95-2024: global marine sediment and ice core chronostratigraphy for the last $110 \mathrm{kyr}$. Earth Planet Sci Lett 183:161-177

Stott L, Poulsen C, Lund S, Thunell R (2002) Super ENSO and global climate oscillations at millennial time scales. Science 297:222_ 226

Stouffer RJ et al (2005) Investigating the causes of the response of the thermohaline circulation to past and future climate change. J Clim 19(8):1365-1387

Svensson A, Andersen KK, Bigler M, Clausen HB, Dahl-Jensen D, Davies SM, Johnsen SJ, Muscheler R, Parrenin F, Rasmussen SO, Röthlisberger R, Seierstad I, Steffensen JP JP, Vinther BM (2008) A 60,000 year Greenland stratigraphic ice core chronology. Climate Past 4:47-57

Trenberth KE, Stepaniak DP, Caron JM (2000) The global monsoon as seen through the divergent atmospheric circulation. J Clim 13:3969-3993

Vidal L, Labeyrie L, Cortijo E, Arnold M, Duplessy JC, Michel E, Becque S, van Weering TCE (1997) Evidence for changes in the North Atlantic deep water linked to meltwater surges during the Heinrich events. Earth and Planet Sci Lett 146:13-27

Wang Y, Cheng H, Edwards RL, He Y, Kong X, An Z, Wu J, Kelly MJ, Dykoski CA, Li X (2005) The Holocene Asian monsoon: links to solar changes and North Atlantic climate. Science 308:854-857

Wang C, Enfield DB (2001) The tropical Western Hemisphere Warm Pool. Geophys Res Lett 28(8):1635-1638

Wang C, Enfield DB, Lee S, Landsea CW (2006) Influences of the Atlantic Warm Pool on Western Hemisphere summer rainfall and Atlantic hurricanes. J Clim 19(12):3011-3028

Watts WA (1975) A late Quaternary record of vegetation from Lake Annie, south-central Florida. Geology 3:344-346

Weldeab S, Schneider RR, Kölling M (2006) Deglacial sea surface temperature and salinity increase in the western tropical Atlantic in synchrony with high latitude climate instabilities. Earth Planet Sci Lett 241:699-706

Whitmore J, Gajewski K, Sawada M, Williams JW, Shuman B, Bartlein PJ, Minckley T, Viau AE, Webb TI, Shafer S, Anderson P, Brubaker L (2005) Modern pollen data from North America and Greenland for multi-scale palaeoenvironmental applications. Quat Sci Rev 24:1828-1848

Wild M, Ohmura A (1999) The role of clouds and the cloud-free atmosphere in the problem of underestimated absorption of solar radiation in GCM atmospheres. Phys Chem Earth 24:261-268

Willard DA, Bernhardt CE, Brooks GR, Cronin TM, Edgar T, Larson R (2007) Deglacial climate variability in central Florida, USA. J Palaeo 251(3-4):366-382

Zhang R, Delworth TL (2005) Simulated tropical response to a substantial weakening of the Atlantic thermohaline circulation. J Clim 18(12):1853-1860

Ziegler M, Nurnberg D, Karas C, Tiedemann R, Lourens LJ (2008) Persistent summer expansion of the Atlantic Warm Pool during glacial abrupt cold events. Nat Geosci 1:601-605 